\title{
An Integrated Model to Enhance Residents' Support for Future Festivals Case Study: WOMAD (CACERES, 2018, SPAIN)
}

\author{
Carlo Alessandro Sirianni, Parisa Sabbagh* \\ DISA-MIS Department, University of Salerno, Fisciano, Italy \\ Email: *psabbagh@unisa.it
}

How to cite this paper: Sirianni, C. A., \& Sabbagh, P. (2020). An Integrated Model to Enhance Residents' Support for Future Festivals Case Study: WOMAD (CACERES, 2018, SPAIN). Journal of Service Science and Management, 13, 659-687.

https://doi.org/10.4236/jssm.2020.134042

Received: April 28, 2020

Accepted: August 23, 2020

Published: August 26, 2020

Copyright $\odot 2020$ by author(s) and Scientific Research Publishing Inc. This work is licensed under the Creative Commons Attribution International License (CC BY 4.0).

http://creativecommons.org/licenses/by/4.0/

\begin{abstract}
Festivals are of great importance due to their social, cultural, economic and environmental impacts. Understanding the impacts of festivals and planning to maximize the positive impact of these festivals requires research and study in the geographical area of each region. These studies provide insights into the behavior of different variables. In this paper, residents "support for future festivals is examined on the basis of subjective well-being and how community feeling affects residents" perceptions of the social benefits of festivals. We conducted a structured questionnaire for 375 local residents in Caceres (Spain) during the annual WOMAD Festival (2018) to test the proposed integrative model using the (SEM) method. The result indicated that residents' subjective well-being is a strong positive predictor of residents' support for future festivals. Furthermore, the significant relationships between residents' sense of community, perception of festivals, social benefits, and their subjective well-being were found to support each other. These findings could be valuable for central governments to pursue the policies to improve residents' well-being and quality of life; they could also be beneficial for festival organizers in terms of mobilizing residents to enhance their support toward future festivals. Given the scattered findings of previous research studies and the lack of a multiple mediation model to expressly explore the linkage between residents' sense of community, subjective well-being, resident behavioral intentions, and festival social benefits, rather than by simply through a single mediator, the present paper is the first study to evidence empirical explorations to date that address the association between these constructs in the context of tourism and festivals. Therefore, it provides guidance to future research as well.
\end{abstract}




\section{Keywords}

Sense of Community, Community Benefits, Individual Benefits, Subjective Well-Being, Resident Support, Caceres, Spain, WOMAD

\section{Introduction}

Spanish culture is a mix of historical attractions and modern thinking. The culture and tradition of this country is rich and unique. Its people's lifestyle, culture and natural beauty attract many tourists. One of these beautiful attractions is the country's festivals. Festivals have important and positive economic, social and environmental impacts. Mental well-being is one of the most important individual factors that are subject to change and public policy (Yolal et al., 2016). Based on studies by researchers such as Ballantyne et al. (2014) and Packer \& Ballantyne (2011); Festivals promote tourism in countries and sustainability depends on individual and social variables such as subjective well-being and resident behavioral goals and social benefits of the festival. Festivals are emerging as a fast-growing sector in the tourism and leisure industry and can have a significant impact on the host communities (Bagiran \& Kurgun, 2016). Consequently, there is a growing interest among academics to examine the impacts of festivals on host communities (Pavlukovic, Armenski, \& Alcántara, 2017); however, the sustainable development of an event is impossible without understanding its social consequences on the local community and residents, which are key stakeholders in any community-based festival tourism (Song, Xing, \& Chathoth, 2015). Accordingly, it is vital to examine the perceptions of local residents about tourism development, in general, and events, in particular, since the overall acceptance or rejection of an event and the extent to which the residents will be ready to support it depends on the social impacts it has on the host community (Dinaburgskaya \& Ekner, 2010).

When exploring issues pertaining to community life, the psychological sense of community is a key construct to describe people's perception of their experience within the community. Empirical explorations of the sense of community have been common in a range of community settings but have not received much attention within festival literature. To the best of our knowledge, there is almost no empirical substantiation to date that explores how the sense of community is related to residents' behavioral intentions. To bridge these gaps, in this study, we propose the psycho-social process in the form of the sense of community as an enabler that influences residents' perceptions of festivals and social benefits to support future festivals through residents' subjective well-being.

On the other hand, several studies report that participation in tourism can contribute positively to subjective well-being (Morgan, Pritchard, \& Sedgley, 2015; Naidoo \& Sharpley, 2016, Yolal, Gursoy, Uysal, Kim, \& Karacaoğlu, 2016). Subjective well-being embraces individuals' both emotional and cognitive evalu- 
ations of their lives and their conceptualizations of happiness, peace, fulfillment, and life satisfaction (Diener, Oishi, \& Lucas, 2003). Yet, this concept has rarely been discussed in festival literature; specifically, studies on the linkage between subjective well-being and residents' behavioral intention to support festivals have not yet been attempted in festivals areas. Accordingly, the next theoretical contribution of this study comes from exploring the influence of residents' subjective well-being on resident support for future festivals.

Finally, although there have been some studies that explore resident support on tourism and festivals, given the scattered findings and also due to the lack of a multiple mediation model to expressly explore the linkage between residents' sense of community, festival social benefits, subjective well-being, and resident support for future festivals, the present study attempts, rather than by simply through a single mediator, to build a new integrative model through a set of putative mediators that consider subjective well-being as a putative mediator that transmits the effects of festival social benefits to resident support in future festivals. Accordingly, it is the first study that evidences empirical explorations to date as it tests a model that explores the association among these constructs in the context of tourism and festivals. Therefore, in addition to making a valuable contribution to the existing literature, this study can potentially extend our current theoretical knowledge while providing guidance to spur future research.

\section{Literature Review}

\subsection{Sense of Community}

Numerous studies have examined the role of sense of community in community creation (for example, Omoto \& Packard, 2016; Talo, Mannarini, \& Rochira, 2014). These studies have examined the relationship between community feeling and community participation. According to research, community participation has been interpreted as an important indicator of community development. Llopis-Amorós et al. (2019) stated that community feeling enables individuals to adapt their behaviors to perceptions of the environment and social relationships. Similarly, the findings of Omoto and Packard (2016) showed that sense of community in society is positively associated with participation and environmental activities. Therefore, it is expected that a common sense, which is influenced by the interaction of people with other social structures in society, will positively affect community participation and the extent to which individuals interact with one another.

\subsection{Social Benefits of Festivals}

Hosting festivals can create socio-cultural benefits for the host community. These festivals can create a sense of community among residents. They can also provide opportunities for cultural exchanges between visitors and hosts and provide entertainment and recreational opportunities for locals (Arcodia \& Whitford, 2006). Festivals provide opportunities for bringing together members of the 
community to work toward a common goal. On achieving this goal and staging a successful community festival, individual members of the community are able to feel proud of their efforts and may benefit from an increased sense of identity (Small, 2007). They can also help host communities create and promote a positive image of the host community in the minds of both residents and prospective visitors. Therefore, festivals have been receiving increasing attention from government entities and destinations mostly because of the anticipated benefits these festivals can bring to their region and the lives of residents (Burgan \& Mules, 2000). Community festivals are an opportunity for community members to come together to socialize and be entertained in order to enhance their sense of belonging and community identity and create an increased sense of community well-being by way of enhancing their relationship networks and social capital. For individual community members, personal benefits such as increased self-esteem, a sense of contribution and self-worth, and personal and life satisfaction can result from involvement in a community festival. By doing so, they are more likely to retain the support of the local community, which is an essential ingredient in the success of an event, especially small-scale community festivals (Small, 2007). The hosting of a festival provides opportunities for a wide range of positive social impacts on the residents of the host community, including the opportunity to develop new skills, a sense of identity, self-esteem, and the formation of new relationships and social networks. In addition, community festivals can encourage increased levels of volunteerism within a community as well as further community group activities of various kinds (Allen et al., 2010).

\subsection{Subjective Well-Being}

The concept of subjective well-being embraces both the emotional and cognitive evaluations of individuals' lives and their conceptualization of happiness, peace, fulfillment, and life satisfaction (Diener et al., 2003). The concept of subjective well-being has evolved over the past several decades as research has continued to reveal its multidimensional, dynamic, person-specific, and culture-specific nature (King, Vivian, \& Novo, 2014). Subjective well-being plays an important role in individuals' lives in helping them achieve their optimal functioning capacity, having confidence in achieving important goals, and having the motivation and energy to persistently overcome obstacles faced in the course of life (Yolal et al., 2016). Numerous studies have examined festivals and other social issues using the variables mentioned above. In this part of the research a number of studies are presented and finally the research model is presented.

\section{Previous Research}

Albanesi, Cicognani, and Zani (2007), in their study, investigated the relationship between sense of community, civic engagement, and social well-being in a sample of Italian adolescents. Results showed that sense of community predicts social well-being and explains some of the associations between civic engagement and social well-being. Dinaburgskaya and Ekner (2010), who examined the 
festival's social consequences experienced by the residents of Göteborg, identified how certain sociodemographic characteristics of the residents relate to their perceptions of these impacts. Wombacher, Tagg, Bürgi, \& MacBryde, (2010) in their study, present a German sense of community scale for use in military settings. Their study helps clarify whether the claim of the universality of SOC goes beyond cultural and linguistic borders. The findings of Nawijn and Mitas's (2012) research indicated that perceived tourism impacts are associated with residents' subjective well-being and life satisfaction.

Kim, Uysal, and Sirgy (2013) indicated that community residents' perceptions of tourism impacted residents' satisfaction in particular life domains and overall life satisfaction. The results of the study by Van Winkle and Woosnam (2014), which examined by the relation between SOC and perceived social impacts of festival events, reveal that residents who feel that the community meets their needs (because of their greater sense of needs fulfillment) also recognize the benefits of the festival. Woo, Kim, and Uysal (2015) studied the association between residents' perceived value of tourism development, life satisfaction, and local residents' support to tourism development. Song et al. (2015) proposed a new approach in which festival performance and satisfaction were putative mediators that transmitted the effects of the festival benefits of support toward future festivals.

Yolal et al. (2016) reported the relationship between the socio-cultural impacts of a festival and the subjective well-being of local residents using the data collected from the local attendees of a film festival. They concluded that community benefits and cultural/educational benefits are positive predictors of the subjective well-being of residents.

Almeida-Garcaí, Peláez-Fernández, Balbuena-Vázquez, and Cortés-Macias (2016), in their study, examined residents' perceptions of the impact of tourism and the profiles of the residents according to their socio-demographic characteristics. Results show the significant influence socio-demographic variables have on the perception of tourism impact. The results of Uysal, Sirgy, Woo, and Kim's study (2016) showed that tourism experiences and activities have a significant effect on both tourists' overall life satisfaction and the well-being of residents. The perceptions of residents toward the impacts of tourism development in the Emirates of Abu Dhabi, examined by Malalla Hammad et al. (2017), found that all residents recognize positive impacts of tourism development and support tourism development.

Pavlukovic et al. (2017) examined how the cultural dimensions of the two different nations relate to the residents' perceptions of the impacts of the festivals. Vico, Uvinha, and Gustavo (2018) focused on the analysis of the socio-geographical impacts of sports mega-events on the local community in the São Paulo at the 2014 FIFA World Cup Brazil. They concluded that involving residents, local companies, and institutions can lead to investments in the territory, economic growth, greater social cohesion, and the strengthening of the local identity.

Studies in this part of the research have examined different aspects of festivals. 
In these studies, the social and cultural variables affecting the holding of festivals have been studied and the economic advantages of the festivals for different regions have been analyzed. But a prospective study has not been done to provide more basic guidelines for organizing festivals with more participants. The present study seeks to identify the reasons for the increase in festival attendees by dividing the benefits of the festivals into two sections: social and individual (Table 1).

Table 1. The key past researches related to our research.

\begin{tabular}{|c|c|c|}
\hline \multicolumn{2}{|c|}{ Research Title } & \multirow{2}{*}{$\begin{array}{l}\text { Authors } \\
\text { (Getz, 2010). }\end{array}$} \\
\hline 1 & The nature and scope of festival studies. & \\
\hline 2 & $\begin{array}{l}\text { Social Impacts of the Way Out West Festival on the } \\
\text { Residents of the City of Göteborg. }\end{array}$ & $\begin{array}{l}\text { (Dinaburgskaya \& } \\
\text { Ekner, 2010). }\end{array}$ \\
\hline 3 & $\begin{array}{l}\text { Indigenous Cultural Festivals: Evaluating Impact on } \\
\text { Community Health and Wellbeing. }\end{array}$ & (Phipps and Slater, 2010). \\
\hline 4 & $\begin{array}{l}\text { Measuring sense of community in the military: cross-cultural } \\
\text { evidence for the validity of the brief sense of community scale } \\
\text { and its underlying theory. }\end{array}$ & (Wombacher et al., 2010). \\
\hline 5 & $\begin{array}{l}\text { Sense of community and perceptions of festival social } \\
\text { impacts. }\end{array}$ & $\begin{array}{l}\text { (Van Winkle \& Woosnam, } \\
\text { 2014). }\end{array}$ \\
\hline 6 & $\begin{array}{l}\text { Residents' perceptions of tourism development in } \\
\text { Benalmadena (Spain). }\end{array}$ & (Almeida-García et al., 2016). \\
\hline 7 & $\begin{array}{l}\text { Social impacts of music festivals: Does culture impact locals' } \\
\text { attitude toward events? }\end{array}$ & (Pavlukovic et al., 2017). \\
\hline 8 & $\begin{array}{l}\text { The Concept, Dimensions and Methods of Assessment of } \\
\text { Human Well-Being within a Socioecological Context: } \\
\text { A Literature Review. }\end{array}$ & (F. King et al., 2014). \\
\hline 9 & $\begin{array}{l}\text { Impacts of festivals and events on residents } \\
\text { well-being. }\end{array}$ & (Yolal et al., 2016). \\
\hline 10 & $\begin{array}{l}\text { Evaluating perceptions of residents towards impacts of tourism } \\
\text { development. }\end{array}$ & (Malalla Hammad et al., 2017). \\
\hline 11 & $\begin{array}{l}\text { The effects of festival impacts on support intentions based on } \\
\text { residents' ratings of festival performance and satisfaction. }\end{array}$ & (Song et al., 2015). \\
\hline 12 & Sports mega-events in the perception of the local community. & (Vico et al., 2018). \\
\hline
\end{tabular}

\section{Conceptual Model and Hypotheses}

Following the previous researches that were analyzed in Section 3, this study proposes an overarching framework to investigate how the psycho-social process, in the form of a sense of community, acts as an enabler to influence residents' perceptions of festivals' social benefits and encourage residents to support future festivals by improving residents' subjective well-being (Small, 2007). Most of the studies in the fields of tourism and festivals are aimed at the economic impacts of festivals and its influence on locals' support; previous evidence on studies that tackle socio-cultural issues is less. Furthermore, given the scattered findings and the lack of a multiple mediation model to expressly explore the linkage between residents' sense of community, festival social benefits, subjective well-being, and 
resident support for future festivals, the present study is the first study that evidences empirical explorations to date by testing a model that explores the association among these constructs in the context of tourism and festivals. Therefore, it makes a valuable contribution to existing literature and can potentially extend our current theoretical knowledge. The model developed and tested in this study is presented in Figure 1.

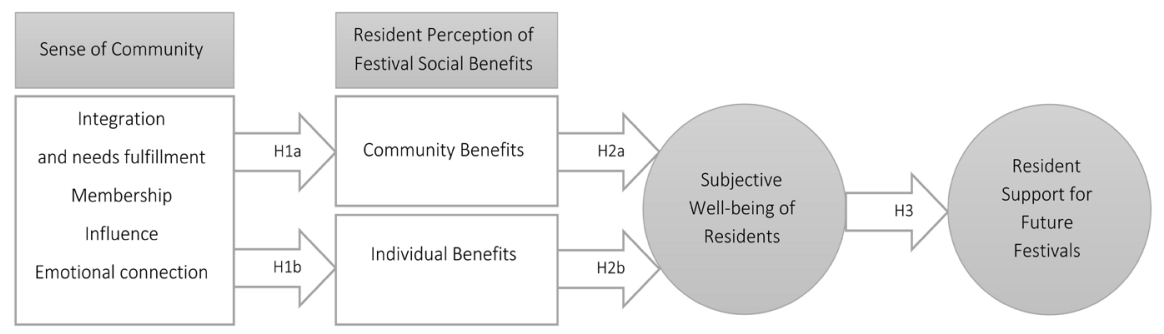

Figure 1. The research conceptual model.

\subsection{The Sense of Community and Community Benefits}

Mannarini and Fedi (2009) found that the relation between sense of community and participation in the aspects of community life were more complex than had been previously demonstrated. Schwarz and Tait's (2007) study results showed a connection between recreation, arts, and cultural events and sense of community. As José del Barrio, Devesa, and Herrero (2012) argued, festivals forge a new urban image and act as a driving force behind cultural creativity and social cohesion more than any other cultural phenomenon. Moreover, Ferdinand and Williams (2013) showed that festivals offer opportunities for community revitalization and cohesiveness. According to Van Winkle and Woosnam (2014), sense of community appears to contribute to community members' ability to see the implications of hosting events. The results of their study showed that greater needs fulfillment and influence resulted in a stronger perception of impacts likely because of heightened awareness of the goings-on within the community. They also found a significant and positive relationship between the shared emotional connection dimension of SOC and community benefits of festivals. To test the abovementioned claims, we advanced the following hypothesis:

$H 1$ a. SOC will be significantly associated with the residents perception of festivals' community benefits.

\subsection{The Sense of Community and Individual Benefits}

As mentioned by Derrett (2003), sense of community contributes to festivals as these events allow community members to share a purpose. Hosting festivals can, therefore, create socio-cultural benefits for the host community, provide opportunities for cultural exchange between visitors and hosts, and provide entertainment and recreational opportunities for locals (Arcodia \& Whitford, 2006). The needs fulfillment dimension of sense of community is based on the premise that individuals have to have their needs met (receive benefits) by the community and that this contributes to the sense of community. Those community members who 
feel more strongly that their community meets their needs are more likely to recognize the benefits of various community opportunities, including festivals (Van Winkle \& Woosnam, 2014). In light of the tourism-based SET research, it seems reasonable to expect that an individual who has a positive relation with a sense of community and who feels that they benefit from this relationship will perceive more benefits from community activities (such as festival and events) (Van Winkle \& Woosnam, 2014). Moreover, Ballantyne, Ballantyne, and Packer (2014) mentioned that music festivals provide an environment that encourages positive psychological outcomes for the attendees. These arguments lead to the following hypothesis:

$H 1$ b. SOC will be significantly associated with the residents' perception of festivals individual benefits.

\subsection{Community Benefits and Subjective Well-Being}

Subjective well-being of residents is considered one of the most critical determinants of their overall quality of life (Kim et al., 2013). Local authorities and central governments continuously initiate policies to improve residents' well-being (Dolan \& Metcalfe, 2012). Festivals are organized by communities for a variety of reasons, including showcasing their cultural heritage, promoting their city, attracting tourists, and providing additional cultural entertainment offerings to local residents, thereby providing opportunities to improve their quality of life (Cudny, Korec, \& Rouba, 2012). As Liang, Cole, and Illum (2008) mentioned, festivals can provide opportunities for excitement, fun, and cultural entertainment for the host community since cultural and leisure activities are positively correlated with socially oriented happiness. Raj and Vignali (2010) stated that festivals are an important expression of human activity and contribute significantly to the social and cultural life of their host communities. Moreover, festivals can help the host communities create and promote a positive image of the host community in the minds of both the residents and prospective visitors (Burgan \& Mules, 2000). Yolal et al. (2016) mentioned that festivals can enhance the image of a community, provide a platform to show others the unique and special characteristics of the community, and contribute to the well-being of the festival goers. Our next hypothesis, therefore, is as follows:

H2a. Residents perception of festivals community benefits will be significantly associated with residents' subjective well-being.

\subsection{Individual Benefits and Subjective Well-Being}

Improving individuals' well-being to a meaningful level has been the fundamental goal of all modern societies as well-being is an indicator of how residents perceive their lives are going (Chen, Jing, Hayes, \& Lee, 2013). Previous studies clearly suggest that attending cultural and social events such as festivals and musical and artistic performances can significantly improve individuals' happiness and life satisfaction (Keyes, Shmotkin, \& Carol, 2002). Mingo and Montecolle 
(2014) demonstrated a link between participation in leisure activities that require socialization; for example, attending a festival with friends can promote subjective well-being more than other leisure activities that do not involve socialization. As illustrated by Packer and Ballantyne (2011), music festival attendance can have a significant positive impact on participants' psychological and social well-being. Since festivals and events provide a number of opportunities for enhancing social interactions and relationships (Organ, Koenig-Lewis, Palmer, \& Probert, 2015), they are likely to play a unique role in improving residents' well-being and quality of life. Moreover, festival attendance fulfills multiple psychological needs by providing opportunities for entertainment, socialization, and novelty seeking; this is also likely to have a significant positive impact on the subjective well-being of the participants (Yolal et al., 2016). The agencies that have the responsibility to take care of indigenous health, education, employment, and other well-being outcomes are realizing that cultural festivals are a powerful space for working effectively with communities on their own terrain: opening dialogue, engaging participation, and working in partnerships to both imagine better futures and deliver results in these crucial areas (Phipps \& Slater, 2010). Based on the aforementioned reasoning, we hypothesized that:

H2b. Residents perception of festivals individuals benefits will be significantly associated with residents' subjective well-being.

\subsection{Subjective Well-Being and Resident Support for Future Festivals}

The direct effect of perceived benefits of festivals on resident support has been supported by some studies (Nunkoo \& Ramkissoon, 2012). In this study, we examined the indirect causal linkages between the perceived benefits of festivals and residents' support for future festivals. Indeed, we explored the role of sense of community as an enabler construct for influencing resident behavioral intention to support future festivals through the augmentation of the level of residents' subjective well-being. Consequently, we proposed a hypothesis that the enhancement of residents' subjective well-being will develop residents' support for future festivals. Additionally, though explaining resident support on the basis of social exchange theory is useful, a higher level of resident support is the outcome if they perceive that tourism development is beneficial (Nunkoo \& Ramkissoon, 2012; Prayag, Hosany, Nunkoo, \& Alders, 2013). Recently, Song et al. (2015) showed that festival performance and satisfaction are positive predictors of residents' support for festivals. Furthermore, Woo et al. (2015), in their study, indicated a positive relationship between life satisfaction and support for tourism development. In this study, we consider that residents' support for future festivals is a function of causal antecedent as well as residents' subjective well-being. To test this claim, we advanced the following hypothesis:

H3. Residents subjective well-being will be significantly associated with resident support for future festivals. 


\section{The Study Site}

\subsection{Location: Spain, Cáceres}

In the heart of Extremadura, there is an unforgettable place: Cáceres. The cobbled medieval streets of this small and lively city offer delightful surprises around every corner. Cáceres, is a city in central-western Spain, the capital of the Cáceres province. It is the center of civil and religious architecture that is most important in the Spanish Renaissance style, which, in addition to having elements of the Italian Renaissance, is also a mixture of floral and Plateresque gothic. Its historic center was declared a UNESCO World Heritage Site in 1986 on the grounds that, surrounded by walls, it is rich in stone buildings that form a perfectly preserved urban fabric.

\subsection{WOMAD}

WOMAD, the acronym for World of Music, Arts, and Dance, is an international music and arts foundation known primarily for its festivals held in multiple locations across the globe each year (The Editors of Encyclopaedia Britannica, 2015). WOMAD festivals are family-oriented, diverse, and active musical events. Since the first festival in the UK in 1982, WOMAD has held more than 160 festivals, creating events in twenty-seven countries and islands all over the world (Eventbrite, 2017). WOMAD started being celebrated in 1992 and has been celebrated every year in Cáceres from May $10^{\text {th }}$ to $13^{\text {th }}$. It is a free intercultural event. In addition to musical shows of different formations and soloists, other activities, such as workshops, parades, film screenings, literary recitals, exhibitions, global market or meals of the world in our city, which is a fusion of the different cultures of the world, are also organized.

\section{Materials and Methods}

\subsection{Research Instrument}

\section{Evaluate the reliability and validity of the questionnaire}

A structured survey instrument with standard items was utilized for the data collection. The survey instrument was developed in Spanish and had five sections. The first section included items measuring the residents' sense of community adapted from Peterson et al. (2008), the second section included items to measure residents' perception of the community and individual benefits of the festival adapted from Delamere et al. (2001). The third section of the questionnaire included items to measure residents' subjective well-being adapted from Diener, Horwitz, \& Emmons (1985) and Sirgy (2002). Moreover, in the fourth section residents' support for future festival were measured by the items adapted from Latkova \& Vogt (2012) and Gursoy \& Kendall (2006). Finally, the fifth section of the questionnaire included questions related to demographic characteristics of the respondents. All items in sections one to four were measured on a seven-point Likert-type scale with "strongly agree" at the high end and 
"strongly disagree" at the low end. In this study, Structural Equation Modeling (SEM) was performed using the statistical software LISREL 8.81 and SPSS 11. The confidence coefficient in this research is considered $95 \%$ and, hence, the error coefficient is 0.05 . Face validity was used to validate the research tool. So, the questionnaires, as a pretest, were distributed between 5 professors and specialists. Then, they were amended based on their reforms. For assessing the reliability of the questionnaire, the Cronbach's Alpha index was used. Since the Cronbach's Alpha coefficient in all of the questionnaire's factors (Table 2) is greater than 0.70 , the reliability of the whole questionnaire (0.929) was confirmed.

\subsection{Data Collection}

We adopted Kline's (2011) recommendation for determining the minimum sample size needed for conducting the structural equation model analysis which is at least 200. On the other hand, Hair et al. (2010) suggested that sample size should be five to ten times the number of indicators/items of the questionnaire. Since our proposed model has 32 parameters, we needed 160 to 320 respondents. In order to emphasize the importance of effective and accurate data collection and also to increase the voluntary participation of Cáceres residents, we invited a professional expert ${ }^{1}$ with in-depth experience in sociology and cultural anthropology to supervise and train the staff responsible for data collection. The questionnaires were handed out at the entrances of the WOMAD Festival to potential respondents from among the Cáceres residents and were immediately collected upon completion. Of the 400 delivered questionnaires, 383 were returned. However, 8 were incomplete and thus eliminated from further analysis. As a result, a total of 375 usable questionnaires were retained for the main analysis. Table 3 shows the demographic profile of the participants. Almost more than half of the respondents were female (53.6\%). Similarly, almost more than half of them were married (67.7\%). Most of the participants were between 35 and 44 years old (30.1\%). Slightly more than one-third of the respondents had a Bachelor's degree (39.46). The occupations of the participants showed a reasonable variety: $22.8 \%$ were white-collar employees while $12.4 \%$ were blue-collar employees. Slightly more than one fourth of the participants were students (27.2\%). Moreover, 14.8\% of the participants were educators. Slightly more than one fourth of the participants were unemployed (25.6\%). This profile of the respondents reflected a suitable motivation to conduct the next research with the aim of examining the economic impact of festivals on the employment status of the Caceres residents according to the results of our study, which presented the support of the Caceres residents for future festivals. Also, Table 4 presents the descriptive statistics survey indicators such as the number of respondents, minimum, maximum, average, standard deviation, skewness and kurtosis indicates.

${ }^{1}$ Dr. Maurizio Caselli: Professor in Music, the Conservatory of Bologna; Ph.D. in Urban Planning and Social Policy, University of Bologna. 
Table 2. Reliability of the questionnaire.

\begin{tabular}{ccc}
\hline Research Factors & Number of Questions & Cronbach's Alpha \\
\hline Sense of Community & 8 & 0.863 \\
Community Benefits & 8 & 0.854 \\
Individual Benefits & 8 & 0.820 \\
Subjective well-being & 4 & 0.860 \\
Resident Support & 4 & 0.629 \\
Total & 32 & 0.929 \\
\hline
\end{tabular}

Table 3. Demographic and general characteristics of respondents.

\begin{tabular}{|c|c|c|}
\hline Variable & Frequency & $\%$ \\
\hline \multicolumn{3}{|c|}{ Gender } \\
\hline Female & 201 & 53.6 \\
\hline Male & 174 & 46.4 \\
\hline \multicolumn{3}{|c|}{ Age } \\
\hline Between 18 and 24 & 69 & 18.4 \\
\hline Between 25 and 34 & 85 & 22.6 \\
\hline Between 35 and 44 & 113 & 30.1 \\
\hline Older than 45 & 108 & 28.8 \\
\hline \multicolumn{3}{|c|}{ Marital Status } \\
\hline Single & 121 & 32.2 \\
\hline Married & 254 & 67.7 \\
\hline \multicolumn{3}{|c|}{ Education } \\
\hline Middle school & 83 & 22.13 \\
\hline High school & 97 & 25.86 \\
\hline Bachelor's Degree & 148 & 39.46 \\
\hline Graduate Degree & 31 & 8.26 \\
\hline PH.D & 16 & 4.26 \\
\hline \multicolumn{3}{|c|}{ Occupation } \\
\hline Self-employed & 63 & 16.8 \\
\hline Employed & 47 & 12.53 \\
\hline Casual worker & 56 & 14.93 \\
\hline Unemployed & 96 & 25.6 \\
\hline Student & 74 & 19.73 \\
\hline Retired & 39 & 10.4 \\
\hline Total & 375 & 100 \\
\hline
\end{tabular}


Table 4. Descriptive statistics indicators of research.

\begin{tabular}{ccccccccc}
\hline \multicolumn{2}{l}{ Research Factors Number Minimum } & Maximum & Average & $\begin{array}{c}\text { Standard } \\
\text { Deviation }\end{array}$ & Kurtosis & Skewness \\
\hline $\begin{array}{c}\text { Sense of } \\
\text { Community } \\
\begin{array}{c}\text { Community } \\
\text { Benefits }\end{array}\end{array}$ & 375 & 1.88 & 7.00 & 5.3517 & 1.28739 & -0.209 & -0.631 \\
$\begin{array}{c}\text { Individual } \\
\text { Benefits }\end{array}$ & 375 & 1.50 & 7.00 & 5.2287 & 1.18992 & -0.034 & -0.531 \\
$\begin{array}{c}\text { Subjective } \\
\text { well-being }\end{array}$ & 375 & 1.50 & 7.00 & 5.3287 & 1.6443 & -0.057 & -0.631 \\
$\begin{array}{c}\text { Resident } \\
\text { Support }\end{array}$ & 375 & 1.50 & 7.00 & 5.3893 & 1.21065 & -0.139 & -0.626 \\
\hline
\end{tabular}

\subsection{Statistical Methods and Procedures and Measurement of Research Constructs}

\subsubsection{Confirmatory Factor Analysis (CFA)}

1) The standard Coefficients Model of Analysis (CFA)

In this study, in total, 32 items were used in the analysis (see Table 5). The measurement model was assessed to validate the main five factors in our research model using the statistical methods of confirmatory factor analysis (CFA). Figure 2 shows the standard coefficients of each sub-factor in estimation of its own main factor in the confirmatory factor model, and as evident, all the path coefficients are greater than 0.3 ; hence, those are in a desirable level. Also, the RMSEA index is less than 0.08; hence, all the main five factors can be put in together in the structural equations model (SEM) according to the research model.

\section{2) The meaningful Coefficient Model of Analysis (CFA)}

As can be seen in Figure 3, the RMSEA index is less than 0.08 and the path coefficient $(\beta)$ is greater than 0.3. Moreover, the T-value is greater than 1.96; hence, it can be said that all the relationships between variables and related questions are meaningful. The above table contains all the relationships in the CFA model. As can be seen, in all the relationships, $(\beta)$ is greater than 0.3 , and the $\mathrm{T}$-value is greater than 1.96. Hence, all the relationships between the main variables are meaningful.

\section{3) The fit indices for CFA}

Table 6 refers to the meaningfulness of the confirmatory factor analysis related to the structural validity. As can be seen in Table 6, the value of the test statistic Chi-square/df is less than 3, and most indices are at an appropriate and desirable level. Therefore, we can examine the hypotheses using Structural Equation Modeling (SEM). According to Table 7, in all cases, the correlation coefficients between the variables of the research are meaningful since the significance level is less than 0.05 (Correlation Statistics Significance level is 0.000) and the coefficients are positive. As a result, all the variables within the model have a direct and positive relationship. 


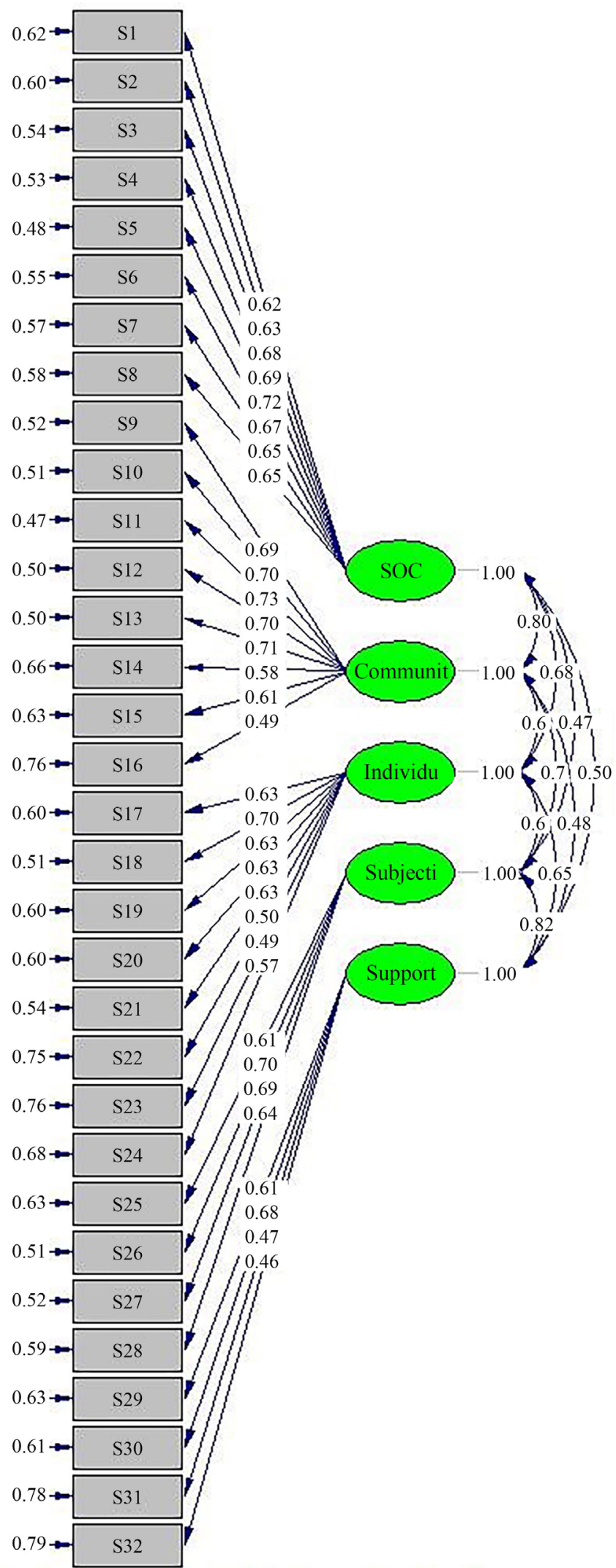

Chi-Square $=831.95, \mathrm{df}=454, \mathrm{P}$-value $=0.00000, \mathrm{RMSEA}=0.047$

Figure 2. The standard coefficients model of (CFA). 


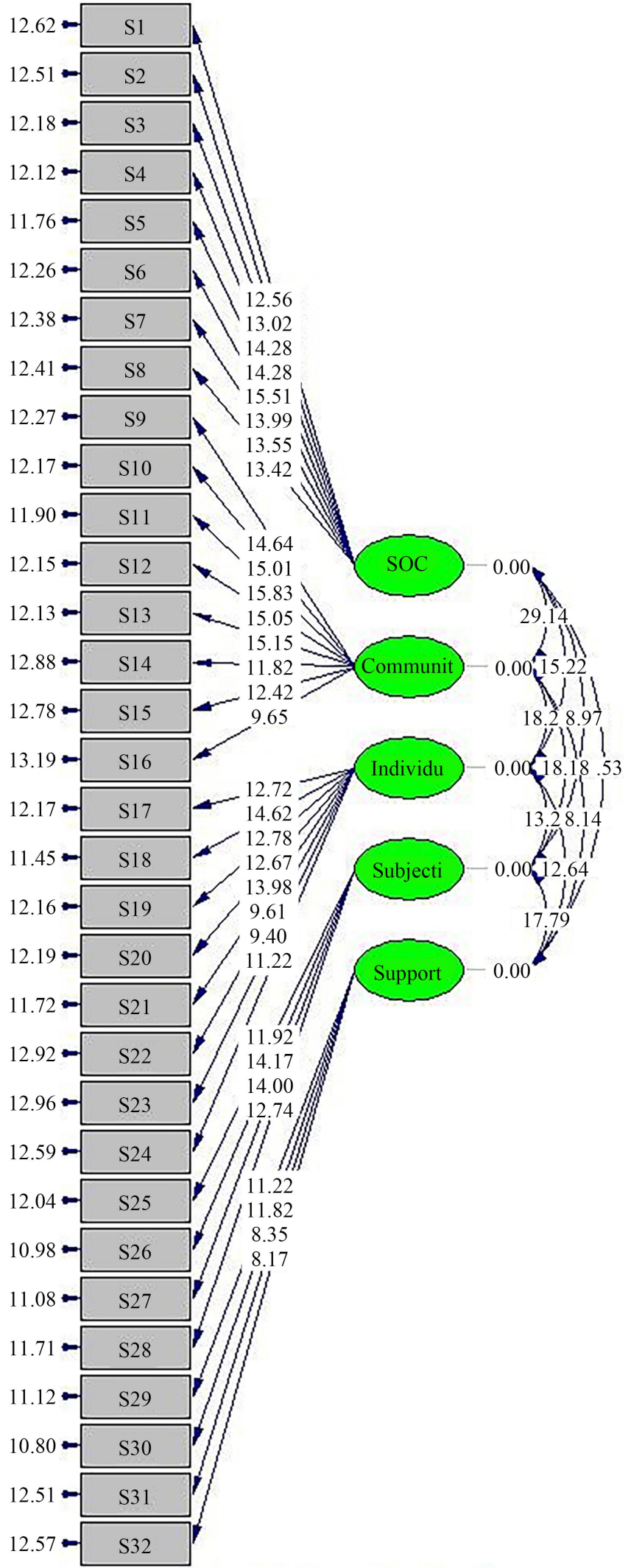

Chi-Square $=831.95, \mathrm{df}=454, \mathrm{P}$-value $=0.00000, \mathrm{RMSEA}=0.047$

Figure 3. The meaningful coefficient model of (CFA). 
Table 5. Relationship between variables and related questions in (CFM).

\begin{tabular}{|c|c|c|c|c|}
\hline & & Related questions & Path Coefficient $(\beta)$ & T-value \\
\hline Q 1 & SOC1 & This community helps me to fulfill my needs. & 0.62 & 12.56 \\
\hline Q 2 & $\mathrm{SOC} 2$ & I can get what I need in this community. & 0.63 & 13.02 \\
\hline Q 3 & $\mathrm{SOC} 3$ & I feel like a member of this community. & 0.68 & 14.28 \\
\hline Q 4 & SOC4 & I belong in this neighborhood. & 0.69 & 14.48 \\
\hline Q 5 & SOC5 & People in this community are good at influencing each other. & 0.72 & 15.51 \\
\hline Q 6 & soc6 & I have a say about what goes on in my neighborhood. & 0.67 & 13.99 \\
\hline Q 7 & SOC7 & I have a good bond with others in this community. & 0.65 & 13.55 \\
\hline Q 8 & SOC8 & I feel connected to this community. & 0.65 & 13.42 \\
\hline Q 9 & PCB1 & Festival enhances general image of the community. & 0.69 & 14.64 \\
\hline Q 10 & РCB2 & My community gains positive recognition as result of festival. & 0.70 & 15.01 \\
\hline Q 11 & РCB3 & Community identity is enhanced through festival. & 0.73 & 15.83 \\
\hline Q 12 & PCB4 & Festival is a celebration of my community. & 0.70 & 15.05 \\
\hline Q 13 & PCB5 & Festival leaves ongoing positive cultural impact in community. & 0.71 & 15.15 \\
\hline Q 14 & PCB6 & Festival helps me show others why my community is unique and special. & 0.58 & 11.82 \\
\hline Q 15 & PCB7 & Festival contributes to sense of community well-being. & 0.61 & 12.42 \\
\hline Q 16 & PCB8 & Festival helps improve quality of life in community. & 0.49 & 9.65 \\
\hline Q 17 & PIB1 & Festival provides opportunities for me to experience new activities. & 0.63 & 12.72 \\
\hline Q 18 & PIB2 & I have opportunity to learn new things. & 0.70 & 14.62 \\
\hline Q 19 & PIB3 & I enjoy meeting festival performers/workers. & 0.63 & 12.78 \\
\hline Q 20 & PIB4 & I feel a personal sense of pride and recognition by participating in festival. & 0.63 & 12.67 \\
\hline Q 21 & PIB5 & Festival provides me opportunity to discover/develop new cultural skills/talents. & 0.68 & 13.98 \\
\hline Q 22 & PIB6 & I am exposed to variety of cultural experiences through festival. & 0.50 & 9.61 \\
\hline Q 23 & PIB7 & Festival acts as a showcase for new ideas. & 0.49 & 9.40 \\
\hline Q24 & PIB8 & Festival contributes to my personal well-being. & 0.57 & 11.22 \\
\hline Q 25 & SWB1 & Overall, I feel this festival has enriched my life. & 0.61 & 11.92 \\
\hline Q 26 & SWB2 & I'm really glad that I participated in this festival. & 0.70 & 14.17 \\
\hline Q 27 & SWB3 & $\begin{array}{l}\text { In this festival, I accomplished my purpose of the experience and this } \\
\text { experience has enriched me in some ways. }\end{array}$ & 0.69 & 14 \\
\hline Q 28 & SWB4 & $\begin{array}{l}\text { This festival was rewarding to me in many ways, that I feel much better about } \\
\text { things and myself with this festival. }\end{array}$ & 0.64 & 12.74 \\
\hline Q 29 & RSFF1 & I think that Cáceres should attract more festival visitors/tourists. & 0.61 & 11.2 \\
\hline Q 30 & RSFF2 & $\begin{array}{l}\text { I believe that Cáceres should be promoted as a festival destination such } \\
\text { as television advertising or brochures for this festival. }\end{array}$ & 0.63 & 11.62 \\
\hline Q 31 & RSFF3 & $\begin{array}{l}\text { I think that Cáceres should develop the visitors' services and facilities } \\
\text { such as hotels, restaurants for this festival. }\end{array}$ & 0.47 & 8.35 \\
\hline Q 32 & RSFF4 & $\begin{array}{l}\text { I think that should be offered information services to festival visitors } \\
\text { such as maps and guidebooks. }\end{array}$ & 0.46 & 8.17 \\
\hline
\end{tabular}


Table 6. Fit indices of the research confirmatory factor model.

\begin{tabular}{ccccccccc}
\hline Fit Indices & RMSEA & $\begin{array}{c}\text { Chi-square/ } \\
\text { df }\end{array}$ & SRMR & GFI & NFI & CFI & IFI & RFI \\
\hline Desirable Amount & $0.08 \geq$ & $3.00 \geq$ & $0.08 \geq$ & $\geq 0.9$ & $\geq 0.9$ & $\geq 0.9$ & $\geq 0.9$ & $\geq 0.9$ \\
Available Amount & 0.050 & 1.923 & 0.066 & 0.87 & 0.95 & & & \\
\hline
\end{tabular}

Table 7. Correlation coefficients between research variables.

\begin{tabular}{cccccc}
\hline $\begin{array}{c}\text { Research } \\
\text { Variables }\end{array}$ & $\begin{array}{c}\text { Sense of } \\
\text { Community }\end{array}$ & $\begin{array}{c}\text { Community } \\
\text { Benefits }\end{array}$ & $\begin{array}{c}\text { Individual } \\
\text { Benefits }\end{array}$ & $\begin{array}{c}\text { Subjective } \\
\text { well-being }\end{array}$ & $\begin{array}{c}\text { Resident } \\
\text { Support }\end{array}$ \\
\hline $\begin{array}{c}\text { Sense of } \\
\text { Community }\end{array}$ & 1 & & & & \\
$\begin{array}{c}\text { Community } \\
\text { Benefits }\end{array}$ & 0.681 & 1 & & & \\
$\begin{array}{c}\text { Individual } \\
\text { Benefits }\end{array}$ & 0.536 & 0.633 & 1 & & \\
$\begin{array}{c}\text { Subjective } \\
\text { well-being }\end{array}$ & 0.387 & 0.586 & 0.503 & 1 & \\
Resident Support & 0.367 & 0.377 & 0.479 & 0.551 & 1 \\
\hline
\end{tabular}

\subsubsection{Structural Equations of Research Model}

\section{1) The Standard Coefficient Model of (SEM)}

In this step, the relationships between the research model structures could be tested. For this purpose, the model was implemented using the LISREL 8.81 software. Considering that the amount of REMSA reported is less than 0.08, in order to make an accurate estimation of the path coefficients for testing the research hypotheses, there is no need for reform. Figure 4 is related to the standardized path coefficients in structural equations, and as can be seen, all the paths between the variables are meaningful.

\section{2) The meaningful Coefficient Model of (SEM)}

Figure 5 is related to the meaningful coefficients in structural equations mod$\mathrm{el}$, and as can be seen, all the T-values between variables are greater than 1.96 and, thus, are meaningful.

\section{3) The fit indices for SEM}

According to Table 8, the fit indices have been investigated, as it can be seen that, in most cases, the fit indices are desirable, which means that the structural equation model was not rejected. Therefore, considering that the structural model fitting indices have been supported and since CFA has shown that the questions of each variable describe that variable well, we examined the research hypotheses based on the SEM.

Table 9 contains all the relationships in the structural model and, as is evident, in all the relationships, the path coefficient $(\beta)$ is positive and greater than 0.3. Moreover, the T-value is greater than 1.96; hence, all the relationships between the main variables are meaningful. As a result, all hypotheses were supported. The results provide strong evidence for causal relationships between the constructs underlying the conceptual model presented in this article. There are several key findings, which are discussed separately in the next section. 


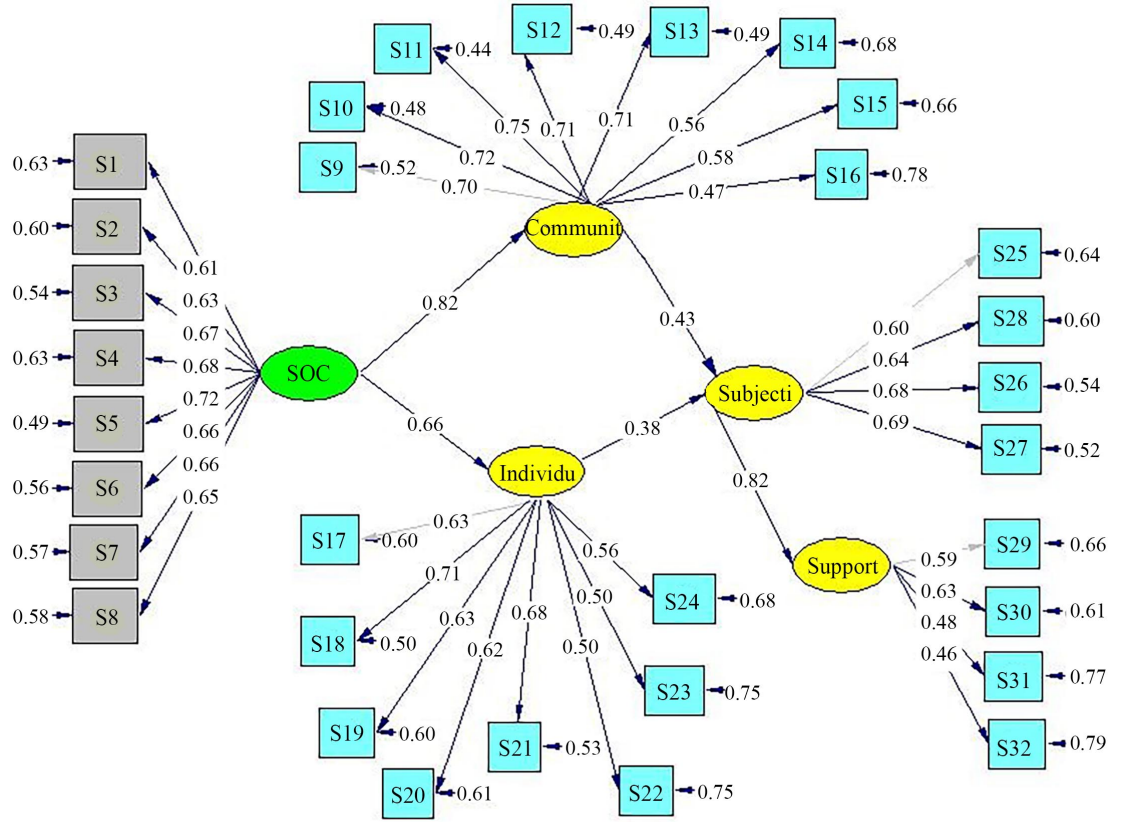

Chi-Square $=882.67, \mathrm{df}=459, \mathrm{P}$-value $=0.00000, \mathrm{RMSEA}=0.050$

Figure 4. The standard coefficient model of (SEM).

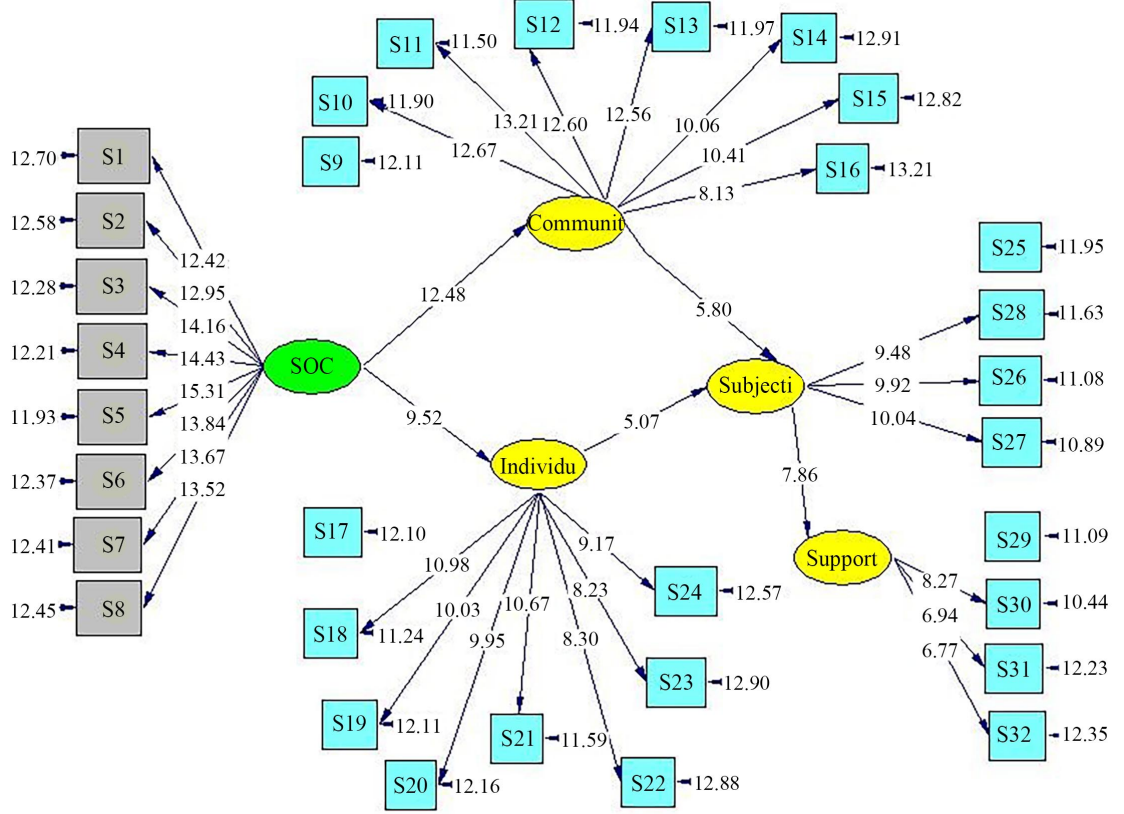

Chi-Square $=882.67, \mathrm{df}=459, \mathrm{P}$-value $=0.00000, \mathrm{RMSEA}=0.050$

Figure 5. The meaningful coefficient model of (SEM).

Table 8. Fit Indices of the research structural model.

\begin{tabular}{ccccccccc}
\hline Fit Indices & RMSEA & $\begin{array}{c}\text { Chi-square/ } \\
\text { df }\end{array}$ & SRMR & GFI & NFI & CFI & IFI & RFI \\
\hline Desirable Amount & $0.08 \geq$ & $3.00 \geq$ & $0.08 \geq$ & $\geq 0.9$ & $\geq 0.9$ & $\geq 0.9$ & $\geq 0.9$ & $\geq 0.9$ \\
Available Amount & 0.050 & 1.923 & 0.066 & 0.87 & 0.95 & & & \\
\hline
\end{tabular}


Table 9. $\beta$ and T-values of the structural model.

\begin{tabular}{|c|c|c|c|c|}
\hline Path & & $\begin{array}{l}\text { Path } \\
\text { Coefficient } \\
(\beta)\end{array}$ & T-value & $\begin{array}{l}\text { Hypothesis } \\
\text { supported/ } \\
\text { rejected }\end{array}$ \\
\hline $\mathrm{H} 1 \mathrm{a}$ & $\begin{array}{l}\text { Sense of community } \rightarrow \text { Residents perception of } \\
\text { community benefits of festival }\end{array}$ & 0.82 & 12.48 & Supported \\
\hline $\mathrm{H} 1 \mathrm{~b}$ & $\begin{array}{l}\text { Sense of community } \rightarrow \text { Residents perception of } \\
\text { individual benefits of festival }\end{array}$ & 0.66 & 9.52 & Supported \\
\hline $\mathrm{H} 2 \mathrm{a}$ & $\begin{array}{l}\text { Residents perception of community benefits of } \\
\text { festival } \rightarrow \text { Subjective well-being of residents }\end{array}$ & 0.43 & 5.80 & Supported \\
\hline $\mathrm{H} 2 \mathrm{~b}$ & $\begin{array}{l}\text { Residents perception of individual benefits of } \\
\text { festival } \rightarrow \text { Subjective well-being of residents }\end{array}$ & 0.38 & 5.07 & Supported \\
\hline $\mathrm{H} 3$ & $\begin{array}{l}\text { Subjective well-being of residents } \rightarrow \text { Residents' } \\
\text { support for future festivals }\end{array}$ & 0.82 & 7.86 & Supported \\
\hline
\end{tabular}

\section{Discussion and Conclusion}

Despite acknowledging that sense of community and residents' perception of festivals impacts may be theoretically linked to an explanation for residents' support in developing tourism and festivals and that residents' perception of festivals' impacts may be related to residents' well-being and that their effects may impact the residents' supportive behaviors, to the best of our knowledge, There are few studies that have examined the relationship between tourism and festivals. Our study contributes to the literature by broadening our understanding of the relative importance of these variables. Moreover, our findings and conclusions may have useful implications in both theory and practice (see Section 8).

The first main result of this study indicates a strong relationship between sense of community and residents' perception of festivals' community benefits (0.82). This conclusion is largely consistent with previous studies that found that the community psychology literature suggests that a greater sense of community should result in more favorable perceptions about the community environment (Van Winkle \& Woosnam, 2014). Additionally, this is in agreement with Almeida-Garcaí et al.'s study (2016), which showed how residents' socio-demographic variables have a significant effect on residents' perceptions of the impact of tourism in their community. This result was also confirmed by the study by Pavlukovic et al. (2017), which showed how the cultural dimensions of host communities influence their perceptions about the impact of festivals.

The second finding of our study demonstrates that sense of community has a positive effect on residents' perception of festivals' individual benefits (0.66). This result was supported by several studies, such as Van Winkle and Woosnam (2014), who stated that it seems reasonable to expect that an individual who has a positive relation with a community and who feels like they benefit from this relationship will perceive more benefits from community activities (such as festivals and events). Also, this finding agrees with Ballantyne et al. (2014) who stated that music festivals have an environment that provide positive psychological outcomes for the attendees. This result was also confirmed by Arcodia and 
Whitford (2006) who demonstrated that organizing a festival increases awareness of the community's resources and expertise and creates social bonds among previously unrelated individuals.

The positive relationship between the perception of a festival, community benefits, and the residents' subjective well-being are verified in our study (0.43). Many studies have shown that activities that provide opportunities for enhancing social interactions and relationships are positively correlated with subjective well-being (Chang, Beck, Simon, \& Dong, 2014; Torres, 2015). In the same vein, Yolal et al.'s (2016) findings revealed that festival community benefits and cultural/educational benefits are positive predictors of the subjective well-being of residents. Furthermore, Liang et al. (2008) said that increased recreational venues can provide opportunities for excitement, fun, and cultural entertainment for the host community and, consequently, contribute to the well-being of local residents. Our result is also consistent with Nawijn and Mitas's (2012) study that found resident attitudes to tourism to have a positive impact on their subjective well-being.

Our study found a positive and significant relationship between residents' perception of festivals' individual benefits and their subjective well-being (0.38). This finding is supported by Andreoni and Galmarini's (2016) study in which they argued that the main advantage of the well-being approach is that it provides a representation of well-being that closely reflects the feelings of individuals. Additionally, Cohen (2004) demonstrated that enhanced social relationships such as festivals improve individuals' well-being by enabling them to gain a sense of belonging. Furthermore, this finding agrees with Phipps and Slater (2010) who indicated that participants' positive experiences with festivals are likely to increase their personal satisfaction, which is likely to result in increases in their overall happiness and, consequently, their subjective well-being.

The most interesting result was the finding that there was a strong relationship between the subjective well-being of residents and resident support for future festivals. As shown in Table 9, the path coefficient between these two variabes is (0.82). Thus this result confirms our hypothesis and supports our argument that the subjective well-being of residents has a strong effect in the improvement of resident support in future festivals. This result, along with the results from Song et al.'s (2015) study, indicated resident satisfaction from the festival is a predictor variable of resident support for future festivals. In addition, it is also consistent with the findings of Woo et al.'s (2015) study where they demonstrated the positive effect of life satisfaction on support for tourism development. This study explores residents' perceptions about the social benefits of festivals in a community; Caceres, Spain, in this case. The results suggest that a sense of community influences residents' perceptions of the social benefits of festivals. The results show that residents are aware of how these connect people and contribute to their perceptions about their subjective well-being; consequently, they support future events that are promising for Caceres's future tourism and the festival development in Spain. 


\section{Theoretical and Managerial Implications}

Most of the research in this field is aimed at the economic impacts of festivals and its influence on locals' support; previous evidence on studies that address socio-cultural issues are less. From a theoretical perspective, the research findings evidence the first empirical explorations to date; these explore how the sense of community is related to residents' behavioral intentions to support future festivals in the context of tourism and festivals. These findings could be contributing to a deeper understanding by providing a more comprehensive understanding of psychological issues related to the festival. They also explain how residents can be encouraged to promote supportive behaviors in the community context. From a practical viewpoint, this study could provide managerial implications to practitioners in several ways: For the long-term success of an event, within a socio-ecological context such as communities, participatory methods such as focus groups with local stakeholders can be applied by festival administrators in the future. With regards to the strong effect the sense of community has on residents' attitudes toward the social impacts of festivals, it is critical to emphasize the importance of sense of community as an infrastructure to construct alimentation to residents' perceptions about festivals' benefits. In this way, we suggest that festival organizers who are committed to maximizing festival benefits should make an effort to engage broadly with residents on an ongoing basis. They must be sure to listen to the community members, especially community members with a lower sense of community; they can also, through the mobilization of a community member with a greater sense of community, influence activities that lead to resident support for festivals. The research findings show a positive relationship between residents' experiences with the festival in terms of perceived social benefits and their subjective well-being. This result could be valuable for local authorities and central governments that are continuously pursuing policies to improve residents' well-being by focusing on a number of opportunities for enhancing social interactions and relationships policies that are likely to increase their personal overall happiness and, consequently, their subjective well-being and quality of life. This is done in accordance with the belief that the subjective well-being of residents' is a strong positive predictor for resident support for future festivals. Therefore, it could be an effective instrument to enhance resident support for future festivals. Indeed, by developing an overarching framework, we came up with a mechanism that proved that sense of community, through indirect causal linkages, influence resident support for future festivals. Based on the findings of this study, festival co-ordination organizations can promote public feeling by promoting different programs for the festival and using communication methods such as internet and national and international media, public participation in this festival. The presence of communication media also enhances people's perception of the festival and increases people's desire to participate in the festival.

The positive relationship between subjective well-being and residents' support for the festival shows that public policies have a great effect on subjective 
well-being and indicate the importance of management policies in managing the country.

\section{Limitations and Suggestions for Future Research}

As with every study, this current one is not without limitations that may provide direction for future studies. Despite the findings of the study, they should be applied cautiously. The present study has focused mainly on the special community; so these results cannot be generalized to all communities with different cultures. Considering the results of Pavlukovic et al.'s (2017) study, which showed the cultural dimensions of how two different nations relate to residents' perception of the impacts of the festivals, it was suggested that future studies should consider applying our research model framework in the context of different cultures or countries to confirm similarities and differences from current findings. Also, further research on various age groups among residents can establish more suitable conclusions and recommendations specific to each sub-segment of residents.

\section{The Research Survey Questionnaire}

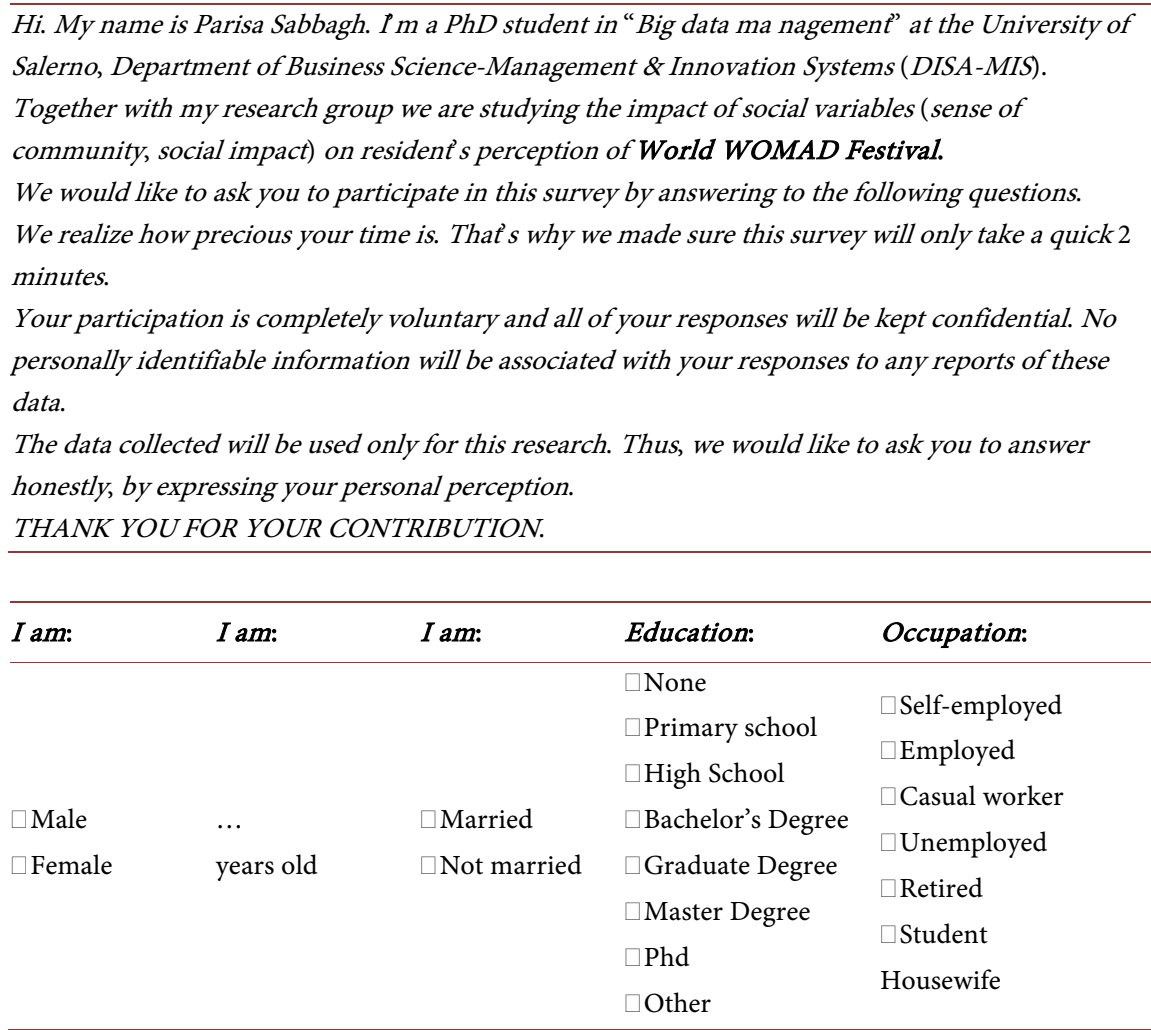

The answers presented below refer to festival resident's perception and evaluation of festival benefits.

Please indicate how strongly you agree or disagree with the following statements by selecting a number from 0 (strongly disagree) to 7 (strongly agree): 
1 This society helps me to fulfill my needs.

2 I can get what I need in this society.

3 I feel like a member of this society.

4 I belong in this neighborhood.

5 People in this society are good at influencing each other.

6 I have a say about what goes on in my neighborhood.

7 I have a good bond with others in this society.

8 I feel connected to this society.

9 Festival enhances general image of the society.

10 My society gains positive recognition as result of festival.

11 Society identity is enhanced through festival.

12 Festival is a celebration of my society.

13 Festival leaves ongoing positive cultural impact in society.

Festival helps me show others why my society is unique and special.

15 Festival contributes to sense of society well-being.

16 Festival helps improve quality of life in society.

17 Festival provides opportunities for me to experience new activities.

18 I have opportunity to learn new things.

19 I enjoy meeting festival performers/workers.

I feel a personal sense of pride and recognition by participating in festival.

Festival provides me opportunity to discover/develop new cultural skills/talents.

I am exposed to variety of cultural experiences through festival.

23 Festival acts as a showcase for new ideas.

24 Festival contributes to my personal health/well-being.

25 Overall, I feel this festival has enriched my life.

26 I'm really glad that I participated in this festival.

In this festival, I accomplished my purpose of the

27 experience and this experience has enriched me in some ways. This festival was rewarding to me in many ways, that I feel much better about things and myself with this festival. I support from offering information services for festival visitors such as maps and guidebooks.

30 I support from promoting the area as a festival destination such as television advertising or brochures for this festival.

31 I support from developing of visitors' services and facilities such as hotels, restaurants for this festival.

32 I support attracting more festival visitors/tourists. 


\section{The WOMAD in Cáceres}
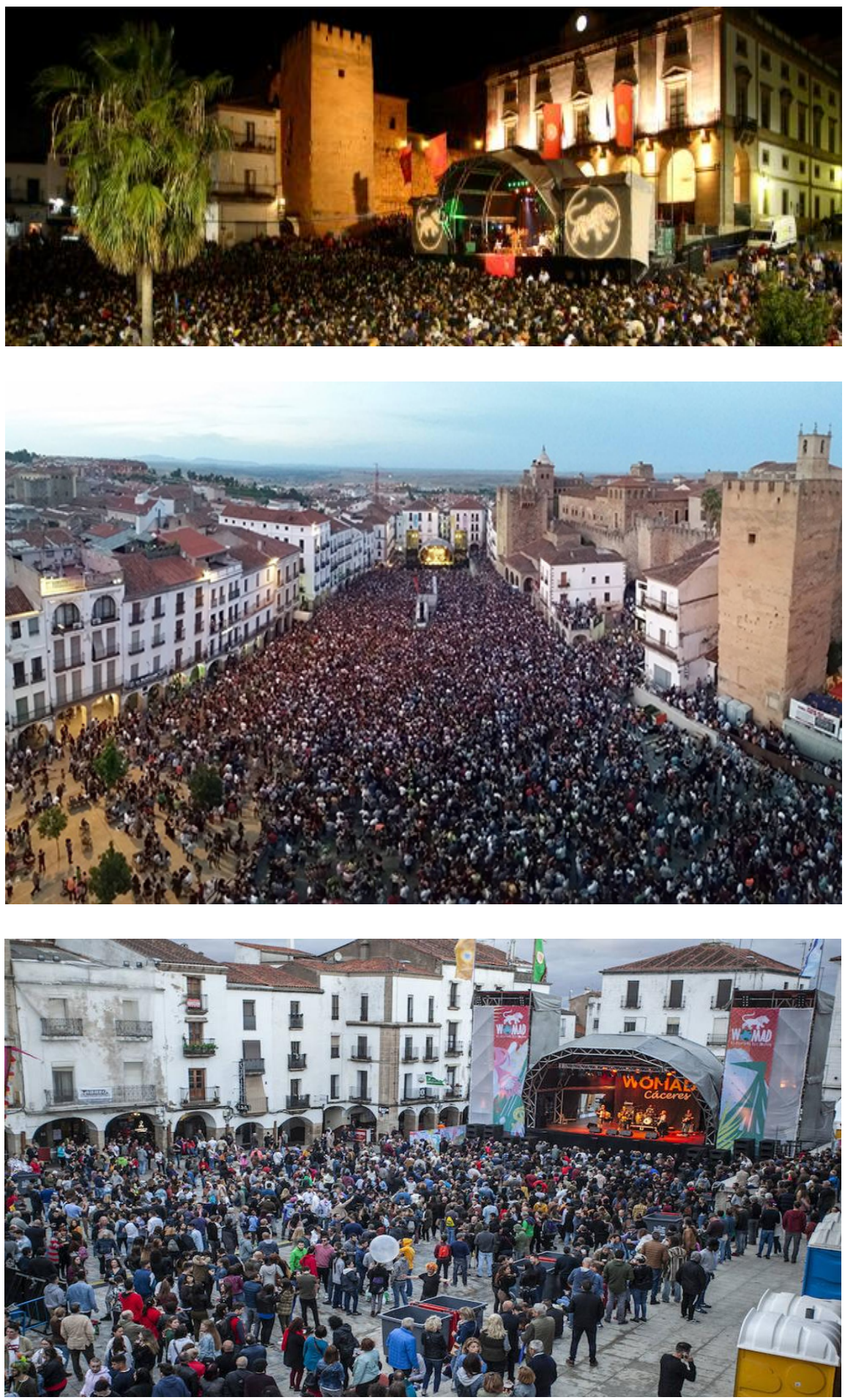

\section{Acknowledgements}

We would like to express our deep appreciation to Dr. Maurizio Caselli for his kind cooperation in the supervision of this research study's data collection team. 

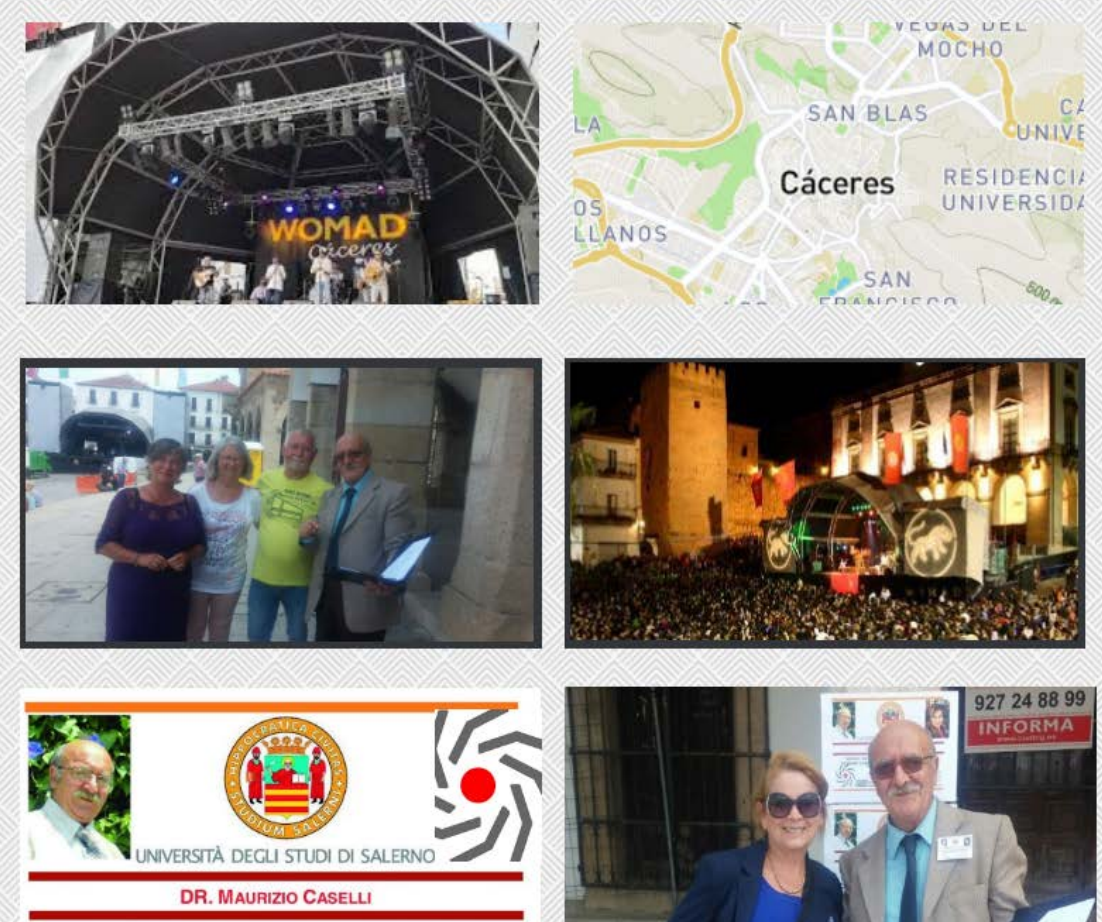

SURVEY ON THE IMPACT OF SOCIAL FACTORS ON SURVEY ON THE IMPACT OF SOCIAL FACTORS ON
RESIDENT'S PERCEPTION OF WORLD WOMAD FESTIVAL RESIDEN
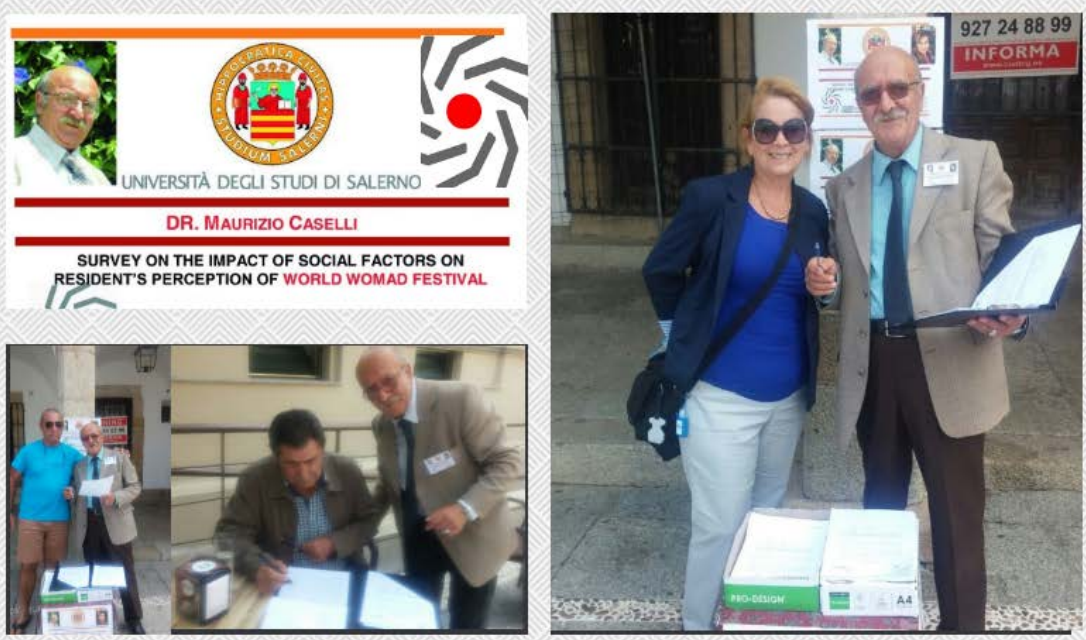

\section{Conflicts of Interest}

The authors declare no conflicts of interest regarding the publication of this paper.

\section{References}

Albanesi, C., Cicognani, E., \& Zani, B. (2007). Sense of Community, Civic Engagement and Social Wellbeing in Italian Adolescents. Journal of Community \& Applied Social Psychology, 17, 387-406. https://doi.org/10.1002/casp.903

Allen, J., O’Toole, W., Harris, R., \& McDonnell, I. (2010). Festival and Special Event Management (5th ed.). Milton, Queensland: Wiley Australia.

Almeida-García, F., Peláez-Fernández, M. Á., Balbuena-Vázquez, A., \& Cortés-Macias, R. (2016). Residents' Perceptions of Tourism Development in Benalmadena (Spain). Tourism Management, 54, 259-274. https://doi.org/10.1016/j.tourman.2015.11.007

Andreoni, V., \& Galmarini, S. (2016). Mapping Socioeconomic Well-Being across EU Regions. International Journal of Social Economics, 43, 226-243.

https://doi.org/10.1108/IISE-09-2014-0178

Arcodia, C., \& Whitford, M. (2006). Festival Attendance and the Development of Social 
Capital. Journal of Convention \& Event Tourism, 8, 1-18. https://doi.org/10.1300/J452v08n02 01

Bagiran, D., \& Kurgun, H. (2016). A Research on Social Impacts of the Foça Rock Festival: The Validity of the Festival Social Impact Attitude Scale. Current Issues in Tourism, 19, 930-948. https://doi.org/10.1080/13683500.2013.800028

Ballantyne, J., Ballantyne, R., \& Packer, J. (2014). Designing and Managing Music Festival Experiences to Enhance Attendees' Psychological and Social Benefits. Musicae Scientiae, 18, 65-83. https://doi.org/10.1177/1029864913511845

Burgan, B., \& Mules, T. (2000). Event Analysis: Understanding the Divide between Cost Benefit and Economic Impact Assessment. In J. Allen, R. Harris, L. Jago, \& J. Veal (Eds.), Events beyond 2000: Setting the Agenda (pp. 46-52). Ultimo: Australian Centre for Event Management.

Chang, E.-S., Beck, T., Simon, A. M., \& Dong, X. (2014). Psychometric Assessment of the Psychological and Social Well-Being Indicators in the PINE Study. Journal of Aging and Health, 26, 1116-1136. https://doi.org/10.1177/0898264314543471

Chen, F., Jing, Y., Hayes, A., \& Lee, J. M. (2013). Two Concepts or Two Approaches? A Bifactor Analysis of Psychological and Subjective Well-Being. Journal of Happiness Studies, 14, 1033-1068. https://doi.org/10.1007/s10902-012-9367-x

Cohen, S. (2004). Social Relationships and Health. American Psychologist, 59, 676-684. https://doi.org/10.1037/0003-066X.59.8.676

Cudny, W., Korec, P., \& Rouba, R. (2012). Residents' Perception of Festivals-The Case Study of Łódź. Slovak Sociological Review, 44, 704-728.

Delamere, T. A., Wankel, L. M., \& Hinch, T. D. (2001). Development of a Scale to Measure Resident Attitudes toward the Social Impacts of Community Festivals, Part I: Item Generation and Purification of the Measure. Event Management, 7, 11-24.

https://doi.org/10.3727/152599501108751443

Derrett, R. (2003). Making Sense of How Festivals Demonstrate a Community's Sense of Place. Journal of Event Management, 8, 49-58. https://doi.org/10.3727/152599503108751694

Diener, E. D., Horwitz, J. A., \& Emmons, R. (1985). Happiness of the Very Wealthy. Social Indicators Research, 16, 263-274. https://doi.org/10.1007/BF00415126

Diener, E. D., Oishi, S., \& Lucas, R. E. (2003). Personality, Culture, and Subjective Well-Being: Emotional and Cognitive Evaluations of Life. Annual Review of Psychology, 54, 403-425. https://doi.org/10.1146/annurev.psych.54.101601.145056

Dinaburgskaya, K., \& Ekner, P. (2010). Social Impacts of the Way Out West Festival on the Residents of the City of Göteborg (Master's Thesis). Göteborg: Göteborg University.

Dolan, P., \& Metcalfe, R. (2012). Valuing Health: A Brief Report on Subjective Well-Being versus Preferences. Medical Decision Making, 32, 578-582.

https://doi.org/10.1177/0272989X11435173

Eventbrite (2017).

https://www.eventbrite.co.uk/blog/case-studies/case-study-womad-festival-great-custo mer-experience-ds0d

Ferdinand, N., \& Williams, L. N. (2013). International Festivals as Experience Production Systems. Tourism Management, 34, 202-210.

https://doi.org/10.1016/j.tourman.2012.05.001

Getz, D. (2010). The Nature and Scope of Festival Studies. International Journal of Event Management Research, 5, 1-47. https://doi.org/10.1108/17852951011029298

Gursoy, D., \& Kendall, K. W. (2006). Hosting Mega Events: Modeling Locals' Support. Annals of Tourism Research, 33, 603-623. https://doi.org/10.1016/j.annals.2006.01.005 
Hair, J. F., Black, W. C., Babin, B. J., \& Anderson, R. E. (2010). Multivariate Data Analysis: A Global Perspective. New Jersey: Pearson Prentice Hall.

Hammad, N. M., Ahmad, S. Z., \& Papastathopoulos, A. (2017). Evaluating Perceptions of Residents towards Impacts of Tourism Development. Emirates of Abu Dhabi, United Arab Emirates Tourism Review, 72, 448-461. https://doi.org/10.1108/TR-03-2017-0046

José del Barrio, M., Devesa, M., \& Herrero, L. C. (2012). Evaluating Intangible Cultural Heritage: The Case of Cultural Festivals. City, Culture and Society, 3, 235-244.

https://doi.org/10.1016/j.ccs.2012.09.002

Keyes, C. L. M., Shmotkin, D., \& Carol, D. R. (2002). Optimizing Well-Being: The Empirical Encounter of Two Traditions. Journal of Personality and Social Psychology, 82, 1007-1022. https://doi.org/10.1037/0022-3514.82.6.1007

Kim, K., Uysal, M., \& Sirgy, M. (2013). How Does Tourism in a Community Impact the Quality of Life of Community Residents? Tourism Management, 36, 527-540. https://doi.org/10.1016/j.tourman.2012.09.005

King, F. M., Vivian, F. R., \& Novo, E. M. L. (2014). The Concept, Dimensions and Methods of Assessment of Human Well-Being within a Socioecological Context: A Literature Review. Social Indicators Research, 116, 681-698.

https://doi.org/10.1007/s11205-013-0320-0

Kline, R. B. (2011). Convergence of Structural Equation Modeling and Multilevel Modeling. In Handbook of Methodological Innovation (Chapter 26). Thousand Oaks, CA: Sage.

Latkova, P., \& Vogt, C. A. (2012). Residents' Attitudes toward Existing and Future Tourism Development in Rural Communities. Journal of Travel Research, 51, 50-67. https://doi.org/10.1177/0047287510394193

Liang, Y., Cole, S. T., \& Illum, S. F. (2008). Benefits Received and Behavioural Intentions of Festival Visitors in Relation to Distance Travelled and Their Origins. International Journal of Event Management Research, 4, 12-23.

Llopis-Amorós, M., Gil-Saura, I., Ruiz-Molina, M. E., \& Fuentes-Blascoc, M. (2019). Social Media Communications and Festival Brand Equity: Millennials vs Centennials. Journal of Hospitality and Tourism Management, 40, 134-144. https://doi.org/10.1016/j.jhtm.2019.08.002

Mannarini, T., \& Fedi, A. (2009). Multiple Senses of Community: The Experience and Meaning of Community. Journal of Community Psychology, 37, 211-227.

https://doi.org/10.1002/jcop.20289

Mingo, I., \& Montecolle, S. (2014). Subjective and Objective Aspects of Free Time: The Italian Case. Journal of Happiness Studies, 15, 425-441. https://doi.org/10.1007/s10902-013-9429-8

Morgan, N., Pritchard, A., \& Sedgley, D. (2015). Social Tourism and Well-Being in Later Life. Annals of Tourism Research, 52, 1-15. https://doi.org/10.1016/j.annals.2015.02.015

Naidoo, P., \& Sharpley, R. (2016). Local Perceptions of the Relative Contributions of Enclave Tourism and Agritourism to Community Well-Being: The Case of Mauritius. Journal of Destination Marketing Management, 5, 16-25.

https://doi.org/10.1016/j.jdmm.2015.11.002

Nawijn, J., \& Mitas, O. (2012). Resident Attitudes to Tourism and Their Effect on Subjective Well-Being: The Case of Palma de Mallorca. Journal of Travel Research, 51, 531-541. https://doi.org/10.1177/0047287511426482 
Nunkoo, R., \& Ramkissoon, H. (2012). Power, Trust, Social Exchange and Community Support. Annals of Tourism Research, 39, 997-1023. https://doi.org/10.1016/j.annals.2011.11.017

Omoto, A., \& Packard, C. (2016). The Power of Connections: Psychological Sense of Community as a Predictor of Volunteerism. The Journal of Social Psychology, 156, 272-290. https://doi.org/10.1080/00224545.2015.1105777

Organ, K., Koenig-Lewis, N., Palmer, A., \& Probert, J. (2015). Festivals as Agents for Behaviour Change: A Study of Food Festival Engagement and Subsequent Food Choices. Tourism Management, 48, 84-99. https://doi.org/10.1016/j.tourman.2014.10.021

Packer, J., \& Ballantyne, J. (2011). The Impact of Music Festival Attendance on Young People's Psychological and Social Well-Being. Psychology of Music, 39, 164-181. https://doi.org/10.1177/0305735610372611

Pavlukovic, V., Armenski, T., \& Alcántara, J. M. (2017). Social Impacts of Music Festivals: Does Culture Impact Locals' Attitude toward Events in Serbia and Hungary? Tourism Management, 63, 42-53. https://doi.org/10.1016/j.tourman.2017.06.006

Peterson, N. A., Speer, P. W., \& McMillan, D. W. (2008). Validation of a Brief Sense of Community Scale: Confirmation of the Principal Theory of Sense of Community. Journal of Community Psychology, 36, 61-73. https://doi.org/10.1002/jcop.20217

Phipps, P., \& Slater, L. (2010). Indigenous Cultural Festivals: Evaluating Impact on Community Health and Wellbeing. Melbourne: Globalism Research Center, RMIT University.

Prayag, G., Hosany, S., Nunkoo, R., \& Alders, T. (2013). London Residents' Support for the 2012 Olympic Games: The Mediating Effect of Overall Attitude. Tourism Management, 36, 629-640. https://doi.org/10.1016/j.tourman.2012.08.003

Raj, R., \& Vignali, C. (2010). Creating Local Experiences of Cultural Tourism through Sustainable Festivals. European Journal of Tourism, Hospitality and Recreation, 1, 51-67.

Schwarz, E. C., \& Tait, R. (2007). Recreation, Arts, Events and Festivals: Their Contribution to a Sense of Community in the Colac-Otway Shire of Country Victoria. Rural Society, 17, 125-138. https://doi.org/10.5172/rsj.351.17.2.125

Sirgy, M. J. (2002). The Psychology of Quality of Life. Dordrecht: Kluwer Academic. https://doi.org/10.1007/978-94-015-9904-7

Small, K. (2007). Social Dimensions of Community Festivals: An Application of Factor Analysis in the Development of the Social Impact Perception (SIP) Scale. Event Management, 11, 45-55. https://doi.org/10.3727/152599508783943219

Song, Z., Xing, L., \& Chathoth, P. K. (2015). The Effects of Festival Impacts on Support Intentions Based on Residents' Ratings of Festival Performance and Satisfaction: A New Integrative Approach. Journal of Sustainable Tourism, 23, 316-337. https://doi.org/10.1080/09669582.2014.957209

Talo, C., Mannarini, T., \& Rochira, A. (2014). Sense of Community and Community Participation: A Meta-Analytic Review. Social Indicators Research, 117, 1-28. https://doi.org/10.1007/s11205-013-0347-2

The Editors of Encyclopaedia Britannica (2015). https://www.britannica.com/topic/WOMAD

Torres, E. (2015). The Influence of Others on the Vacation Experience: An Ethnographic Study of Psychographics, Decision-Making and Group Dynamics among Young Travelers. Journal of Hospitality Marketing \& Management, 24, 826-856. https://doi.org/10.1080/19368623.2015.960991

Uysal, M., Sirgy, M., Woo, E., \& Kim, H. (2016). Quality of Life (QOL) and Well-Being 
Research in Tourism. Tourism Management, 53, 244-261.

https://doi.org/10.1016/j.tourman.2015.07.013

Van Winkle, C. M., \& Woosnam, K. M. (2014). Sense of Community and Perceptions of Festival Social Impacts. International Journal of Event and Festival Management, 5, 22-38. https://doi.org/10.1108/IJEFM-01-2013-0002

Vico, R. P., Uvinha, R. R., \& Gustavo, N. (2018). Sports Mega-Events in the Perception of the Local Community. The Case of Itaquera Region in São Paulo at the 2014 FIFA World Cup Brazil. Soccer \& Society, 20, 810-823.

https://doi.org/10.1080/14660970.2017.1419471

Wombacher, J., Tagg, S., Bürgi, T., \& MacBryde, J. (2010). Measuring Sense of Community in the Military: Cross-Cultural Evidence for the Validity of the Brief Sense of Community Scale and Its Underlying Theory. Journal of Community Psychology, 38, 671-687. https://doi.org/10.1002/jcop.20388

Woo, E., Kim, H., \& Uysal, M. (2015). Life Satisfaction and Support for Tourism Development. Annals of Tourism Research, 50, 84-97. https://doi.org/10.1016/j.annals.2014.11.001

Yolal, M., Gursoy, D., Uysal, M., Kim, H., \& Karacaoğlu, S. (2016). Impacts of Festivals and Events on Residents Well-Being. Annals of Tourism Research, 61, 1-18. https://doi.org/10.1016/j.annals.2016.07.008 